\title{
Adaptation Strategies of Dairy Farmers to Combat Climate Variability in Karnataka State, India
}

\author{
J. Parameswaranaik ${ }^{*}$, A.P. Verma and M.N. Sawant \\ Dairy Extension Div., ICAR- National Dairy Research Institute, Karnal-132001, Haryana, India \\ *Corresponding author
}

\begin{tabular}{|c|c|}
\hline & A B S T R A C T \\
\hline & \multirow{6}{*}{$\begin{array}{l}\text { Dairy farming plays a prominent role in strengthening India's rural economy. It has the } \\
\text { potential to act as an instrument to bring about socio-economic transformation, but in } \\
\text { recent days climate variability affects the dairy farming and it became the serious } \\
\text { consideration. Climate variability refers to the way climate fluctuates yearly above or } \\
\text { below a long-term average value. It has been considered as one of the most serious long- } \\
\text { term challenge faced by dairy farmers, in this context it is important to know about the } \\
\text { adaptation strategies followed by the dairy farmers in combating the climate variability } \\
\text { vagaries. The present study was conducted in purposively selected Northern dry zone of } \\
\text { Karnataka with } 120 \text { dairy farmers, the major findings of the study were, Majority of the } \\
\text { respondents were following adaptation strategies like keeping, promoting and interested in } \\
\text { local breeds ( } 60.83 \%) \text {, About } 42.50 \text { percent of dairy farmers made Changes in micro- } \\
\text { climate in cattle shed/stall and } 47.50 \text { percent of respondents were providing extra } \\
\text { concentrate, minerals supplementation and feed additives to their livestock etc. It was also } \\
\text { found that all the adaptation techniques are local specific, require no external help and are } \\
\text { inherently scientific. Dairy farmers used to follow the cost effective adaption strategies. } \\
\text { Documentation and validation of such practices and techniques should be done and it can } \\
\text { be used for further capacity building programmes. }\end{array}$} \\
\hline & \\
\hline & \\
\hline Article Info & \\
\hline & \\
\hline & \\
\hline
\end{tabular}

\section{Introduction}

The climate variability is increasingly becoming an important consideration of our lives. Climate variability refers to the way climate fluctuates yearly above or below a long-term average value. The warming trend in India over the past century was estimated to be $0.60{ }^{\circ} \mathrm{C}$. The IPCC (2007) predicted that by the year 2100 increase in global average surface temperature may be between 1.8 and $4.0^{\circ} \mathrm{C}$, with global average temperature increases by $1.5-2.5^{\circ} \mathrm{C}$. Approximately 20-30 percent of plant and animal species are expected to be at risk of extinction (IPCC, 2007). Climate variability refers to the way climate fluctuates yearly above or below a long-term average value, and it has been considered as one of the most serious longterm challenge faced by dairy farmers (Maiti et al., 2014).

Adaptation to climate change and variability is now considered as an important response option worthy of research and assessment, not simply to guide the selection of the best mitigation policies, but rather to reduce the vulnerability of groups of people to the impacts of climate change, and hence minimize the costs associated with the 
inevitable (Kane and Shogren 2000, Smit and Pilifosova 2001). This has, in part, stemmed from a realization that a certain amount of climate change will occur, and that society can take concrete steps to minimize the net losses (including taking advantage of opportunities for gains) (Schroter et al., 2005). Different adaptation strategies were talked about especially micro-environment modification like shelter modifications; water cooling or sprinkler system; strategic nutrient supplementation, etc. In this context it is important to know about the adaptation strategies followed by the dairy farmers in combating the climate vagaries. Keeping this in view the present study was conducted with an objective "To ascertain the adaptation strategies followed by the dairy farmers to combat climate variability".

\section{Materials and Methods}

The study was conducted in Northern dry zone area of Karnataka which was purposively selected because of this zone is most frequently exposed to climate change and variability. Raichur and Bellary districts were selected purposively for the study, as these districts holds largest livestock population in study area, from each district, 2 taluks were selected randomly. In the next step, 2 villages were selected from each taluk, randomly. From each selected village, 15 dairy farmers were selected randomly. Thus, total 120 dairy farmers spread over in 8 villages of Manvi, Raichur, Huvinahadagli and Bellary taluks constituted the ultimate sample for the study.

Respondents were asked whether they adopt any measure to cope up with the negative impact of climate change on the binary response yes or no. Those who responded yes, again they were requested to put their response on a three point continuum, namely continued the adoption, discontinued the adoption and never adopted with the score of 2,1 , and 0 on a prelisted adaptation strategies

\section{Results and Discussion}

From table 1 following inferences can be easily drawn, Majority of the respondents were following adaptation strategies like keeping and interested in local breeds (61\%), farmers told that local breeds require less water, resistant to many disease and well survive in adverse climatic condition; About $42 \%$ percent of dairy farmers made Changes in micro-climate in cattle shed/stall in such a way that where animals can live without stress for example planting a tree in the mid of shed for providing shade. And Change in feeding schedule $(31 \%)$ farmers felt that day time feeding during hot summer is the cause of restlessness and discomfort in their animal.

Shifting from large ruminants to small ruminants (44\%) was another important adaptation strategies to combat climate vagaries, it is because of many animals were died during this devastating extreme climatic event. Therefore, to minimize the risk of huge monetary loss and to get relief from fodder scarcity, they adopted small ruminant rearing like sheep and goat Parameswaranaik et al., (2016) has reported the different factors influencing the adaptation strategies.

Migration along with livestock was one of the coping strategies of some of the farmers (14\%) during adverse climatic conditions they will migrate towards the south Karnataka in searching of fodder sources and again after peak summer they turn back to their original places. Majority of the adaptation practices and techniques were locale specific, require no external help and are inherently scientific. Parameswaranaik et al., (2015) had reported that dairy farmers perceived Poor awareness about climate adaptation and mitigation practices were the major constraints. 
Table.1 distribution of respondents based on their adaptation practices followed in dairying

$$
(\mathrm{N}=120)
$$

\begin{tabular}{|c|c|c|c|}
\hline Adaptation strategies & $\begin{array}{c}\mathrm{AC} \\
(\mathrm{P})\end{array}$ & $\begin{array}{l}\mathrm{AD} \\
(\mathrm{P})\end{array}$ & $\begin{array}{l}\text { NA } \\
(\mathrm{P})\end{array}$ \\
\hline Keeping and interested in local breeds & 61 & 26 & 7 \\
\hline $\begin{array}{l}\text { Providing extra concentrate, minerals } \\
\text { supplementation and feed additives to livestock }\end{array}$ & 47 & 35 & 2 \\
\hline Change in feeding schedule to farm animals & 31 & 30 & 46 \\
\hline Change in micro-climate in cattle shed/stall & 42 & 36 & 23 \\
\hline Livestock farming to non - farming (Business) & 8 & 33 & 76 \\
\hline Shifting from large ruminants to small ruminants & 44 & 32 & 25 \\
\hline Reduction in herd size & 38 & 25 & 39 \\
\hline $\begin{array}{l}\text { Plantation of fodder trees around animal shed/ } \\
\text { house to reduce effects of cold and heat waves }\end{array}$ & 21 & 31 & 57 \\
\hline Seasonal migration along with livestock & 4 & 31 & 68 \\
\hline $\begin{array}{l}\text { Providing bedding material for livestock during } \\
\text { extreme winter/ cold conditions }\end{array}$ & 79 & 6 & 0.00 \\
\hline
\end{tabular}

AC- Adoption continued, AD- Adoption discontinued, NA- Never adopted, P- Percentage

So a large scale climate change literacy programmes has to be developed, in which farmers can participate, learn and adapt effective coping strategies to increase farm production as well as their livelihood security.

Over centuries, farmers have traditionally adapted to climatic changes by building on their in-depth knowledge of the environment. Coping strategies of farmers to various climatic vagaries vary from household to household and region to region based on existing supporting system and their indigenous knowledge. Farmers own perception and local traditional knowledge help them in evolving measures and technique to deal with situations arising due to climatic vagaries. Dairy farmers of northern dry zone of Karnataka have practicing many adaptation strategies like keeping and interested in local breeds and providing bedding material for livestock during extreme winter/ cold conditions etc these measures and techniques are locale specific, require no external help and are inherently scientific. Documentation of such practices and techniques, farmer to farmer dissemination and sharing such innovative approaches at large platforms have helped in influencing research agenda of academic institutions and setting the priorities.

\section{References}

FAO, 2007. Synthesis Report: Effect of climate change on Agriculture and allied sectors, Fao, Rome, 2007, p. 12

IPCC (2007). Synthesis Report: Contribution of Working Groups I, II and III to the Fourth Assessment Report of the Intergovernmental Panel on Climate Change, Core Writing Team, Pachauri $\mathrm{R} \mathrm{K}$ and Reisinger A, IPCC, Geneva, 2008, pp: 45.

Kane S M and Shogren J F. (2000). Linking adaptation and mitigation in climate change policy. Climatic Change 45 (1): 75-102.

Maiti Sanjit, Jha Sujeet Kumar, Garai Sanchita, Nag Arindam, Chakravarty R, Kadian K S, Chandel B S, Datta K K and Upadhyay R C. (2014). Adaptation strategies followed by livestock rearers of coastal Odisha and West Bengal to 
cope up with climate change. Indian journal of Animal Sciences 84(6): pp. 52-59.

Parameswaranaik J, R. Senthil Kumar, Manoj Kumar C.T., Arun Kumar P and R. S. Bhawar (2015). Perceived Constraints of Dairy Farmers towards Climate Variability in Northern Dry Zone of Karnataka State. Journal of Global Communication. 8(2): pp. 171-173.

Parameswaranaik J, R. Senthil Kumar, R. S. Bhawar, N.P. Darshan and Diksha Patel. (2016). Factors influencing adaptation strategies by livestock owners to combat climate variability in Karnataka state: Application of ordered logistic regression model. Indian journal of Animal Sciences 86(9):pp7478.

Schroter D, Polsky C and Patt A. (2005). Assessing vulnerabilities to the effects of global change: an eight step approach. Mitigation and Adaptation Strategies for Global Change 10(4): 573-95.

Smit B and Pilifosova O. (2001). Adaptation to climate change in the context of sustainable development and equity. Climate Change 2001: Impacts, Adaptation and Vulnerability. pp. 877912.

\section{How to cite this article:}

Parameswaranaik, J., A.P. Verma and Sawant, M.N. 2017. Adaptation Strategies of Dairy Farmers to Combat Climate Variability in Karnataka State. Int.J.Curr.Microbiol.App.Sci. 6(11): 3091-3094. doi: https://doi.org/10.20546/ijcmas.2017.611.362 